\begin{tabular}{|l|l|l||}
\hline \multicolumn{2}{|c|}{ PublisherInfo } \\
\hline \hline PublisherName & $:$ & BioMed Central \\
\hline \hline PublisherLocation & $:$ & London \\
\hline \hline PublisherImprintName & $:$ & BioMed Central \\
\hline \hline
\end{tabular}

\title{
Epigenetically unstable
}

\begin{tabular}{|l|l|l||}
\hline \multicolumn{2}{|c||}{ ArticleInfo } \\
\hline \hline ArticleID & $:$ & 4140 \\
\hline \hline ArticleDOI & $:$ & $10.1186 /$ gb-spotlight-20010709-01 \\
\hline \hline ArticleCitationID & $:$ & spotlight-20010709-01 \\
\hline \hline ArticleSequenceNumber & $:$ & 211 \\
\hline \hline ArticleCategory & $:$ & Research news \\
\hline ArticleFirstPage & $:$ & 1 \\
\hline \hline ArticleLastPage & $:$ & 2 \\
\hline \hline & $:$ & RegistrationDate : 2001-07-09 \\
ArticleHistory & $:$ & OnlineDate \\
\hline \hline ArticleCopyright & $:$ & BioMed Central Ltd2001 07-09 \\
\hline \hline ArticleGrants & $:$ & \\
\hline \hline ArticleContext & $:$ & 130592211 \\
\hline \hline
\end{tabular}




\section{Jonathan B Weitzman}

Email: jonathanweitzman@hotmail.com

In the July 6 Science, Humpherys et al. describe extensive analysis of the expression of imprinted genes in mice derived from cloning by nuclear transfer (NT) (Science 2001, 293:95-97). They examined mRNA levels for several imprinted genes including $H 19$ and Igf2, Peg1/Mest, Mest/Grb10, Peg3 and Snrpn. They found that the expression of imprinted genes varied widely between the placentas of cloned embryos and in the organs of newborn cloned mice. $H 19$ expression was often silenced and Igf2 expression was increased compared to controls. These abnormalities correlated with hypermethylation of the H19 differentially methylated region (DMR). Analysis of NT ES-cell clones and subclones revealed similar variations in $\mathrm{H} 19$ and $\mathrm{Peg} l$ expression, differences in methylation and epigenetic heterogeneity. Humpherys et al. used tetraploid complementation and nuclear transfer experiments to show that the expression of imprinted genes varied widely even in mice derived from cells of the same ES-cell subclone. They conclude that the epigenetic state of ES cells is extremely unstable and that mammalian development appears surprisingly tolerant to epigenetic abnormalities.

\section{References}

1. Science, [http://www.sciencemag.org]

2. Hybrid vigor, fetal overgrowth, and viability of mice derived by nuclear cloning and tetraploid embryo complementation. 